\title{
Reviving extinct Mediterranean forest communities may improve ecosystem potential in a warmer future
}

\author{
Paul D Henne ${ }^{1,2,3 * \dagger}$, Ché Elkin ${ }^{3,4}$, Jörg Franke ${ }^{2,5}$, Daniele Colombaroli ${ }^{1,2}$, Camilla Calò ${ }^{1,2}$, Tommaso La Mantia ${ }^{6}$, \\ Salvatore Pasta ${ }^{7}$, Marco Conedera ${ }^{8}$, Orla Dermody ${ }^{9}$, and Willy Tinner ${ }^{1,2,3}$
}

The Mediterranean Basin is the region of Europe most vulnerable to negative climate-change impacts, including forest decline, increased wildfire, and biodiversity loss. Because humans have affected Mediterranean ecosystems for millennia, it is unclear whether the region's native ecosystems were more resilient to climate change than current ecosystems, and whether they would provide sustainable management options if restored. We simulated vegetation with the LANDCLIM model, using present-day climate as well as future climate-change scenarios, in three representative areas that encompass a broad range of Mediterranean conditions and vegetation types. Sedimentary pollen records that document now-extinct forests help to validate the simulations. Forests modeled under present climate closely resemble the extinct forests when human disturbance is limited; under future scenarios, characterized by increased temperatures and decreased precipitation, extinct forests are projected to re-emerge. When combined with modeling, paleoecological evidence reveals the potential of native vegetation to re-establish under current and future climate conditions, and provides a template for novel management strategies to maintain forest productivity and biodiversity in a warmer and drier future.

Front Ecol Environ 2015; 13(7): 356-362, doi:10.1890/150027

$\mathrm{A}^{\mathrm{s}}$ the cradle of Western civilization, the Mediterranean region has sustained large human populations for millennia. Nevertheless, the continued provision of ecosystem services in the region is highly uncertain, given that it is a climate-change "hotspot", where summer warming and drought are likely to intensify during this century. Mediterranean ecosystems may be particularly vulnerable to degradation in a warmer and drier climate. Most vegetation models for the Mediterranean region project declining climatic suitability for economically and ecologically important trees - and concomitant reductions in the ecosystem services they provide - at the warm, dry edges of their current ranges, and increasing risk of catastrophic fire as flammable shrublands replace lowland forests (Schröter et al. 2005; Moriondo et al. 2006). However, extensive variation in climate sensitivity exists among vegetation models (Cheaib et al. 2012). Therefore, individual models require empirical valida-

${ }^{1}$ Institute of Plant Sciences, University of Bern, Bern, Switzerland; 'current address: US Geological Survey, Denver, CO *(phenne@ usgs.gov); ${ }^{2}$ Oeschger Centre for Climate Change Research, University of Bern, Bern, Switzerland; ${ }^{3}$ Department of Environmental Sciences, ETH Zurich, Zurich, Switzerland; ${ }^{4}$ Ecosystem Science and Management, University of Northern British Columbia, Prince George, Canada; ${ }^{5}$ Institute of Geography, University of Bern, Bern, Switzerland; ${ }^{6}$ Department SAF, University of Palermo, Palermo, Italy; ${ }^{7}$ Institute of Biosciences and Bioresources, National Research Council, Palermo, Italy; ${ }^{8}$ Insubric Ecosystems, Swiss Federal Institute for Forest, Snow, and Landscape Research WSL, Bellinzona, Switzerland; ${ }^{9}$ Dupont Pioneer, Manno, Switzerland tion. This is difficult in the Mediterranean region, where millennia of human impacts (eg fire, grazing, logging) have resulted in a mismatch between the distributions and climatic requirements of Mediterranean trees. As a result, models that are calibrated and/or validated with data based on present tree distributions tend to underestimate the potential for native forests to form in warm, dry conditions (Garcia-Valdes et al. 2013). New approaches are therefore needed to understand where native forests can develop in the Mediterranean region under current and future climate conditions, and to identify realistic management goals that can maintain biodiversity and productivity in a changing climate.

Combining paleoecological data with process-based models helps to address these needs by testing assumptions about the climatic tolerances of native Mediterranean forests. During the mid-Holocene (approximately 8000 to 5000 years ago), the ranges of important tree species included warmer and drier habitats than those within the species' present ranges. These species formed communities that are absent today (Carrión et al. 2010; Tinner et al. 2013). Furthermore, closed forests (ie with dense canopies) grew in regions that are now dominated by shrublands. For example, evergreen forests composed of holm oak (Quercus ilex) and olive trees (Olea europaea) occurred along the southern coast of Sicily, the warmest and driest region of Italy (Tinner et al. 2009). Many researchers attribute the widespread decline of Mediterranean forests during the past 7000 years to climatic changes that brought progressively drier conditions to the region (eg Sadori et al. 2011). 
Applying the "aridification hypothesis" to current and future landscapes implies that the re-establishment of the former native forest communities of the mid-Holocene (hereafter "extinct" forest communities) is impossible because the present climate is too dry, and that expansion of the Mediterranean climate zone would have marked consequences for the productivity of European forests. Conversely, reconstructions of past climates that rely on multiple indirect environmental indicators or "proxies" linked late-Holocene forest decline $(<5000$ years ago $)$ - even in the warmest and driest Mediterranean settings - to human impacts rather than climatic change (Colombaroli et al. 2007; Tinner et al. 2009). Process-based models that use plant physiological traits to simulate competition-driven forest dynamics can test these opposing hypotheses by simulating vegetation under present and future climates. Likewise, paleoecological data may corroborate model output, which is critical if simulated forests do not resemble present-day vegetation.

We combined vegetation simulations from the LANDCLIM dynamic landscape vegetation model (Schumacher et al. 2004; Henne et al. 2013) with paleoecological records, to demonstrate how extinct native forests provide renewed potential for Mediterranean ecosystems in both present climates and in a warmer and drier future (Figure 1). We modeled vegetation in three representative regions where Holocene pollen records document the species compositions and structure (eg closed canopy versus shrublands) of past "pristine" forests and the effects of the subsequent intensification of human impacts. The warmest and driest conditions are represented by Gorgo Basso, on the Italian island of Sicily (Tinner et al. 2009), and are associated with vegetation in the so-called thermoMediterranean belt, which extends between $\sim 30-40^{\circ} \mathrm{N}$ and $15^{\circ} \mathrm{W}-40^{\circ} \mathrm{E}$ (Lang 1994). At Lago di Origlio, within the Ticino region of southern Switzerland (Tinner et al. 1999), sub-Mediterranean vegetation $\left(\sim 43-46^{\circ} \mathrm{N}, 15^{\circ}\right.$ $\left.\mathrm{W}-40^{\circ} \mathrm{E}\right)$ grows under a moist and moderately warm climate. Between these sites lies Lago di Massaciuccoli, in

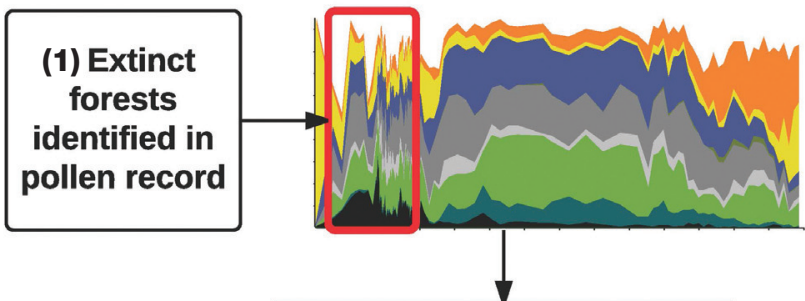

(2a) What drove extinctions?

(2b) Are extinct forests competitive in present and future climate?

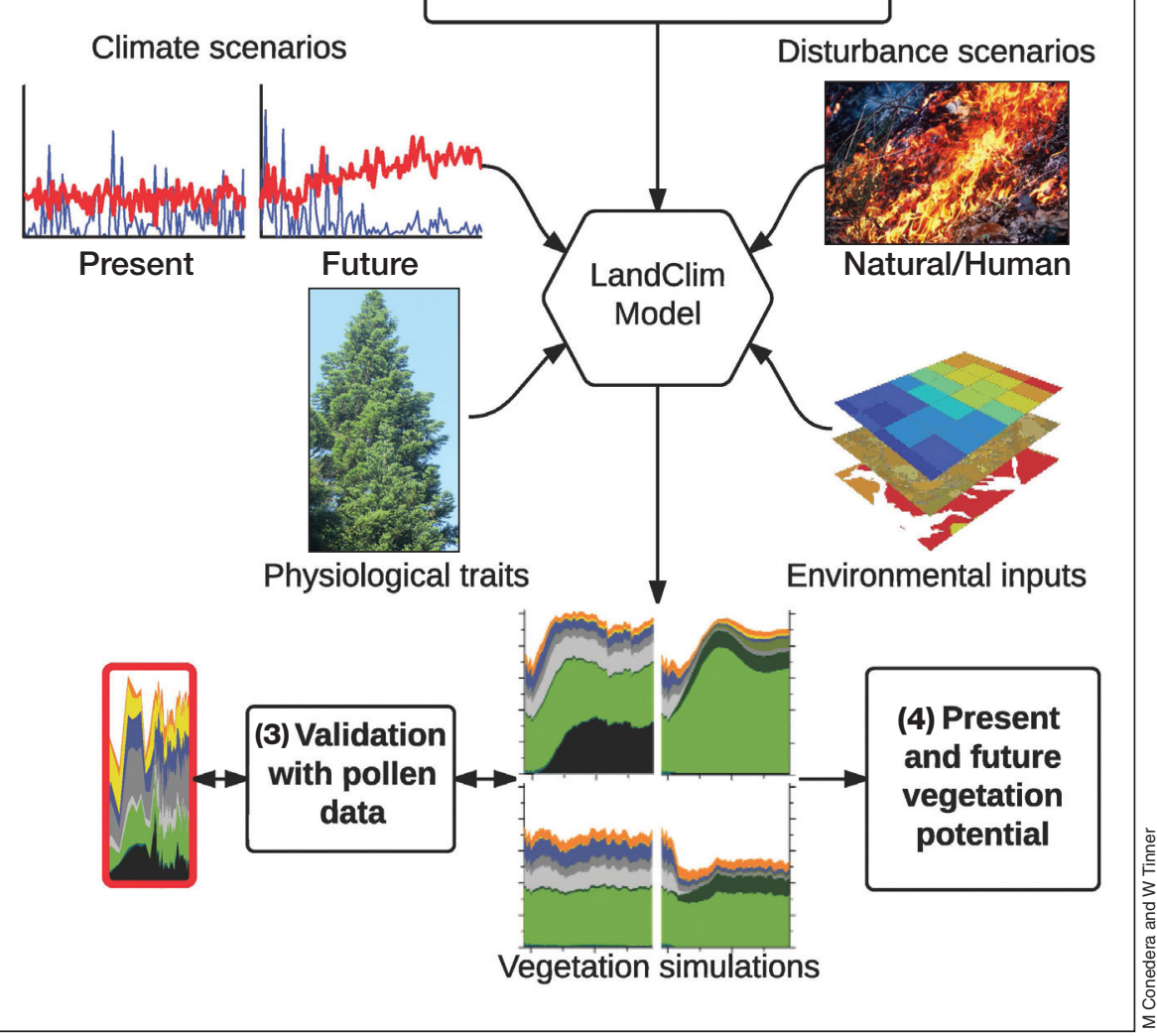

Figure 1. Summary of our research approach using Holocene pollen records and the LANDCLIM dynamic vegetation model to improve understanding of the potential regenerative capacity of native Mediterranean tree and shrub species subjected to present and future environmental conditions. We used separate model scenarios to simulate the impacts of changing climate (present and projected future) and disturbance (separate probabilities for fire ignition and spread, and for the intensity of ungulate browsing). Inputs to LANDCLIM also include tree physiological traits (eg drought, shade, browsing tolerances, and growth rates) and environmental conditions (eg soil depth, elevation, slope, and aspect). Model outputs were validated with local and regional pollen records. Pollen diagram modified from Henne et al. (2013). central Italy's Tuscany region (Colombaroli et al. 2007), with average Mediterranean climatic conditions and mesoMediterranean vegetation $\left(\sim 40-44^{\circ} \mathrm{N}, 15^{\circ} \mathrm{W}-40^{\circ} \mathrm{E}\right)$.

Landscape-level simulations are ideal for our research questions. As compared with global dynamic vegetation models, they feature high spatial resolution (eg 25-m $\times$ 25 - $\mathrm{m}$ grid cells) with more realistic landscape properties, including slope, aspect, and soil variability. Moreover, in 
contrast to species distribution models, dynamic landscape vegetation models simulate interspecific competition and disturbance regimes, which vary with changing climate and land use and are critical determinants of species abundances. We simulated vegetation at each site under present climate using low (pre-human impact) and moderate disturbance scenarios (Henne et al. 2013). At each site, we then projected future vegetation under the A1B emissions scenario of the Intergovernmental Panel on Climate Change.

\section{Methods}

Vegetation dynamics were simulated within $3 \mathrm{~km}$ of three lakes - Gorgo Basso, Lago di Massaciuccoli, and Lago di Origlio - with the LANDCLIM model (Schumacher et al. 2004). Modeled landscapes included all upland forests, shrublands, and grasslands but omitted regions where upland forests cannot develop (ie wetlands, coastal dunes, and cultivated lands). The LANDCLIM model estimates competitive dynamics among cohorts of trees and shrubs in $625-\mathrm{m}^{2}$ grid cells using monthly temperature and precipitation data and landscape-specific soil conditions and topography (Figure 1). Model cells interact to simulate wildfire over the entire landscape. A cumulative beta probability density function relates a drought index to the probability that a fire will ignite and spread. Browsing by wild and domestic ungulates is simulated by varying the probability of seedling establishment. Without browsing, all species have an equal probability of survival; as browsing intensity increases, trees and shrubs with high sensitivity to browsing have a lower probability of establishment than species that are tolerant of browsing (Henne et al. 2013).

We simulated vegetation at each site under low and moderate disturbance using a control scenario with present climate, and future climate scenarios for 2011-3000 AD. Our low disturbance scenario excludes browsing and includes infrequent fire to mimic disturbance regimes that existed before the onset of human impacts on vegetation at the three sites (Tinner et al. 1999, 2009; Colombaroli et al. 2007). Our moderate-disturbance scenario simulates land-use intensification (Henne et al. 2013); simulated browsing limits regeneration of browsing-sensitive species (eg silver fir [Abies alba]), and small, frequent fires reduce overall plant biomass (WebPanel 1). To standardize the start of each model run, we initialized all simulations with a 2000-year model "spin-up" period, using a present-day (1951-2000 AD) climate scenario and moderate disturbance. We developed future climate scenarios by combining output from nine regional climate models from the ENSEMBLES project (Van der Linden and Mitchell 2009) for 2011-2100 AD, with local weather station data from 1951-2000 AD (WebPanel 2). We allowed the vegetation to stabilize in our simulations by applying the climate projected for 2075-2100 AD to 2101-3000 AD. We ranked the scenarios based on the difference between the projected future vegetation and the modern climate control scenario (WebPanel 3); here, we present the future scenario with the median impact on vegetation for each site. LANDCLIM output represents the mean of 10 replicate simulations.

\section{Results and discussion}

\section{Extinct Mediterranean forests are competitive in the present climate}

Forest communities simulated using present-day climate and a low level of disturbance do not resemble today's dominant vegetation. Instead, those communities are consistent with the species compositions of pristine forests that disappeared during the mid to late Holocene. At Gorgo Basso, which is representative of the warmest and driest environments in Europe, Q ilex was the dominant tree in closed, broad-leaved evergreen forests that developed after 5000 calibrated years BC (cal BC). These thermo-Mediterranean forests included $O$ europaea and evergreen shrubs, predominantly Pistacia lentiscus. The present-day landscape, which is dominated by shrubs and grasslands, with few remnant patches of $Q$ ilex forest, developed during the past 2000 years as human impacts substantially increased (Tinner et al. 2009). LANDCLIm simulates Q ilex-dominated forests with large O europaea trees contributing $9 \%$ of the combined total biomass of trees and shrubs (hereafter "biomass") under present climate, if disturbance is low (Figure 2). Increasing disturbance reduces the biomass of trees in the model, and increases the abundance of shrubs, especially Quercus coccifera, which contributes $23 \%$ of biomass. In this scenario, frequent fires prevent O europaea from attaining large size, and its average proportion of biomass declines to $5 \%$, which mirrors the present situation in coastal Sicily. Thus, according to the model, management strategies that limit fire occurrence are probably necessary to revive Q ilex-Olea forests in the present climate.

High potential for the re-establishment of extinct forest types is not limited to Europe's warmest environments. In coastal Tuscany, we project mixed forests of coniferous silver fir (A alba), broad-leaved evergreen oaks (Q ilex), and deciduous oaks (Quercus cerris and Quercus pubescens) under present climate and low disturbance (Figure 3). As in the case of the extinct Q ilex-Olea forests in coastal Sicily, no similar forests exist today. At present, A alba, Europe's tallest tree, is restricted to moist, montane ecosystems and does not form coastal forests under meso-Mediterranean conditions (Tinner et al. 2013). However, pollen and macrofossil data from Lago di Massaciuccoli and several other sites demonstrate that A alba formed forests with Q ilex and other Mediterranean species in lowland Tuscany from 4500-3500 cal BC (Tinner et al. 2013; Di Pasquale et al. 2014), a finding that agrees with our model results. A alba 
is absent from the region at the onset of our simulations, as a result of moderate disturbance being presumed in the model initialization, but expands to contribute $34 \%$ of biomass in the low disturbance scenario. Topography adds another dimension. In our simulations, $A$ alba is abundant on relatively moist northerly slopes and in deep soils, but Q ilex and other Mediterranean species dominate the driest landscape positions. A alba does not expand when subjected to moderate disturbance because fire limits biomass accumulation, and browsing restricts the establishment of this browsing-sensitive species. Instead, simulated forests resemble those that developed after 3500 cal BC, when fire activity increased and deciduous species replaced A alba.

Disturbance also limits the species composition of cooler sub-Mediterranean ecosystems today. At Lago di Origlio, A alba formed forests with deciduous species between 7000 and 3000 cal BC, but was extirpated by increasing anthropogenic disturbance (Tinner et al. 1999). Our simulations also produce forests with A alba and deciduous trees under present climate and low disturbance (Figure 4). A alba is initially absent due to simulated historical moderate disturbance, but expands to contribute $10 \%$ of the biomass and partially replaces deciduous competitors - especially small-leaved lime, Tilia cordata, which is an abundant species today. Fagus sylvatica and Quercus petraea contribute most of the biomass in a species-rich forest that includes $T$ cordata, Carpinus betulus, and Ostrya carpinifolia. Simulations with moderate disturbance and present climate resemble deciduous forests that grow near Lago di Origlio today; A alba is absent while $F$ sylvatica, Q petraea, and T cordata are the most abundant species.

\section{Extinct Mediterranean forests provide viable management goals for the future}

Future climate change will alter the competitive balance between Q ilex and O europaea in thermo-Mediterranean ecosystems. The potential for Q ilex to form forests in our future climate scenario is greatly reduced at Gorgo Basso. Even when subject to low disturbance, Q ilex never grows larger than a shrub and maintains similar abundance as $Q$ coccifera, contributing $8 \%$ of total biomass. However, the more drought-tolerant $O$ europaea attains large size and contributes $51 \%$ of the biomass, and the shrubs Pistacia lentiscus and Phillyrea latifolia are more abundant than in our present climate scenario. These simulated communities are similar to those that formed under drier conditions in the past. Open woodlands (ie without a closed canopy) dominated by $O$ europaea and $P$ lentiscus preceded the formation of closed forests with Q ilex at Gorgo Basso (Figure 2; Tinner et al. 2009), and also grew near the North African coast (Calò et al. 2013; Lebreton et al. in press). Furthermore, woodlands containing overstory O europaea and understory $P$ lentiscus form in northwest Africa today when cutting is prohibited and fire is limited, but shrublands form when disturbance is frequent (Deil et al. 2005). Including moderate disturbance in our future climate scenario also prevents $O$ europaea from forming a canopy and increases the proportion of shrubs.

Quercus ilex forests provide a viable and desirable management goal for a warmer and drier future in mesoMediterranean ecosystems, especially given that our simulated future climate scenario is too dry for A alba to persist at Lago di Massaciuccoli. Instead, with low disturbance, evergreen forests dominated by $Q$ ilex, but includ- 


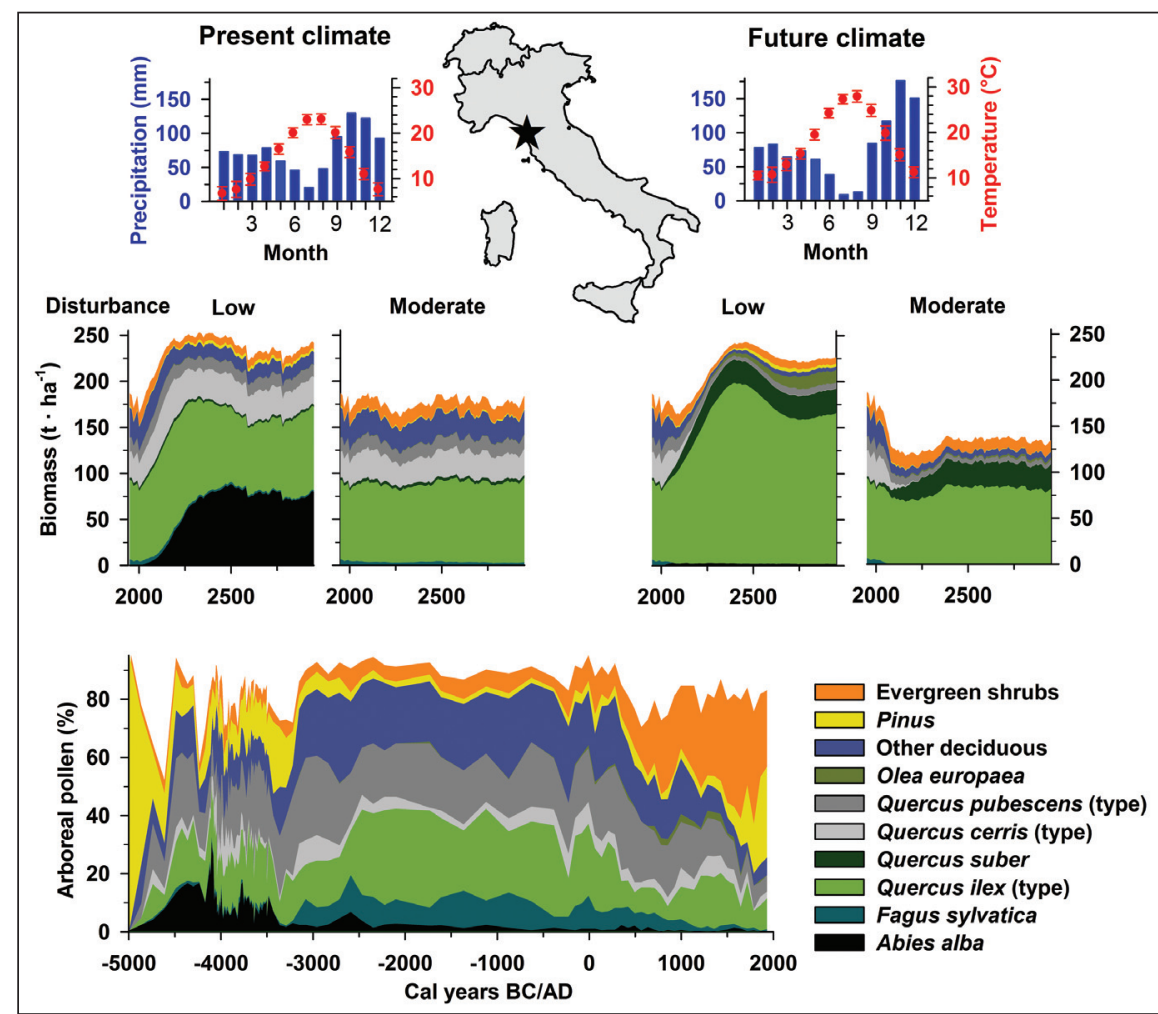

Figure 3. As for Figure 2, except for Lago di Massaciuccoli (Colombaroli et al. 2007). The future climate scenario was developed from the ETHZ-CLM regional climate model. Evergreen shrubs include Phillyrea latifolia, Ilex aquifolium, and Rhamnus alaternus. Pinus in the simulations is Pinus halepensis. Other deciduous species include Fraxinus ornus, Ostrya carpinifolia, and Tilia cordata. Pollen diagram modified from Henne et al. (2013).

ing Quercus suber and O europaea, replace the mixed deciduous and evergreen communities, with only the drought-tolerant deciduous trees, Q pubescens and Fraxinus ornus, contributing $>1 \%$ of simulated biomass. Although this vegetation does not resemble past local communities, pollen data from Gorgo Basso and elsewhere in thermo-Mediterranean southern Europe (Tinner et al. 2009; Carrión et al. 2010) demonstrate that Q ilex forests can develop where the climate is even drier than our future scenario for Lago di Massaciuccoli. Furthermore, Q ilex forests burned less frequently than the open communities that replaced them during the Holocene (Tinner et al. 2009), and have lower flammability than the evergreen shrublands that are currently expanding in the region's abandoned agricultural lands (Azevedo et al. 2013). Therefore, managing to promote late-successional $Q$ ilex forests may help mitigate projected climate-driven increases in wildfire risk in southern Europe (Moriondo et al. 2006), and also maintain ecosystem services such as watershed integrity, sustainable timber production, and carbon sequestration. This important implication applies today in the thermoMediterranean belt $\left(\sim 30-40^{\circ} \mathrm{N}\right)$, and under projected climate change in the meso-Mediterranean belt $\left(\sim 40-44^{\circ} \mathrm{N}\right)$.

Including historical pollen data in our analyses reveals the limitations imposed when only current vegetation is considered in climate-impact research. In the future scenario for Lago di Origlio with low disturbance, A alba becomes the most abundant tree, contributing $67 \%$ of biomass and replacing moisturedemanding species (eg F sylvatica; Figure 4). Yet without unambiguous paleobotanical evidence for abundant A alba at sub-Mediterranean and meso-Mediterranean sites (Tinner et al. 2013; Di Pasquale et al. 2014), projected communities of A alba growing with thermophilous (warmthloving) trees, which lack a modern analog, would appear highly unrealistic. Furthermore, the paleoecological evidence of extinct A alba populations in regions with mild winters raises questions about the validity of previous approaches that limited A alba populations in process-based models by setting a very low $\left(-2^{\circ} \mathrm{C}\right)$ maximum winter temperature for establishment (eg Hickler et al. 2012). Our simulations do not constrain A alba with an unrealistic maximum winter temperature threshold, and are supported by observations that deciduous and evergreen oaks, not A alba, are replacing $F$ sylvatica at the dry edges of its range (Peñuelas et al. 2007), when moderate disturbance is included. In our future scenario with moderate disturbance, $F$ sylvatica and T cordata remain important - but they are partially replaced by evergreen and deciduous oaks, with evergreen $Q$ ilex reaching 23\% of biomass.

\section{Conclusions}

Vegetation simulated under low disturbance conditions and present climate captures the dominant species composition of forests that disappeared from the Italian Peninsula and Sicily during the past 5000 years. Forests of $Q$ ilex and O europaea remain well-suited to the present climate of coastal Sicily, the warmest and driest region of Italy. Likewise, A alba competes with thermophilous species in meso- and sub-Mediterranean ecosystems. These findings refute the hypothesis that the establishment of today's open Mediterranean vegetation (ie maquis and garrigue shrublands) was driven by a drying climate. Instead, our simulations support timeseries analyses of pollen data that link forest decline and the loss of disturbance-sensitive species to agriculture, silviculture, and other human-mediated impacts (Tinner et al. 1999, 2009). Thus, these now-extinct communities provide a template for future management 


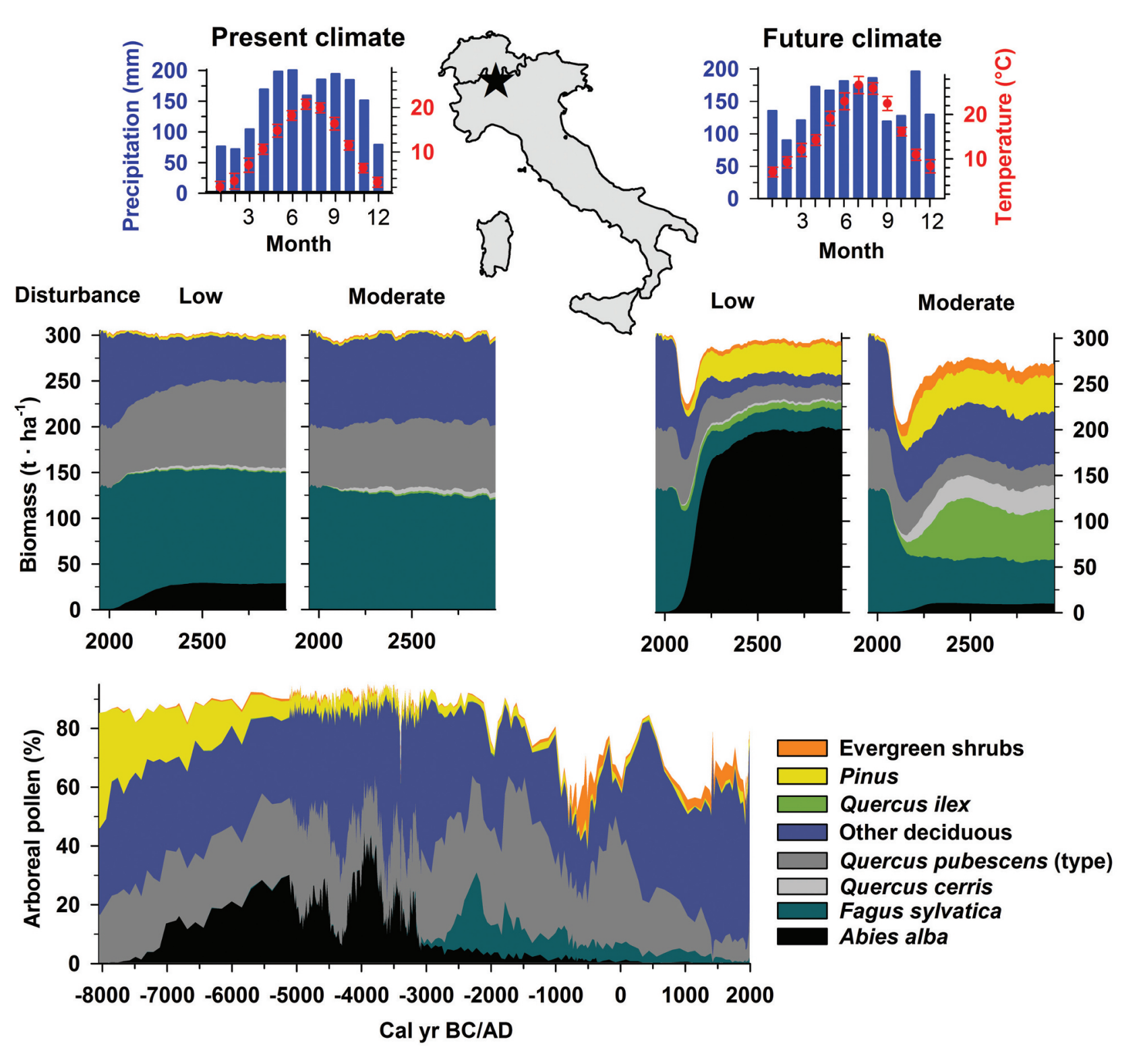

Figure 4. As for Figure 2, except for Lago di Origlio (Tinner et al. 1999). The future climate scenario was developed from the C4IRCA3 regional climate model. Evergreen shrubs are mostly Ilex aquifolium. Pinus in the simulations is Pinus sylvestris. Other deciduous species include Tilia cordata, Ostrya carpinifolia, and Carpinus betulus. Quercus pubescens-type pollen includes Quercus petraea and Quercus robur. We also grouped these species in the model output. However, most of the simulated biomass is $\mathrm{Q}$ petraea.

of native forests in the Mediterranean region that is grounded in past evidence. Although future climate may remain suitable for extinct Mediterranean forest communities, their viability will depend on specific disturbance regimes. For instance, fire suppression in highly flammable, early-successional shrublands may be necessary to establish late-successional evergreen forests with lower flammability. Likewise, A alba saplings require protection from ungulate browsing to re-establish in thermophilous forests. Such management strategies may help revive valuable native forests, especially where agricultural abandonment and cessation of forest grazing have allowed forest and shrubland expansion.
Future management strategies to promote native vegetation should be informed by more than data from extant plant communities. Paleoecological evidence can be used not only to test assumptions about the environmental factors that limit species distributions but also to improve and validate models that project vegetation re-establishment in a changing climate. We argue that restoring these native forests would likely provide valuable ecosystem services and increase ecosystem resilience to future climate change. Extreme mitigation approaches, such as replacing native vegetation with plantations of exotic timber species (eg Eucalyptus, Pseudotsuga), are unnecessary to maintain future productivity and offer a poor sub- 
stitute for diverse native forests that are well-adapted to the Mediterranean climate. The advantages of restoring native forests in this region, including the delivery of ecosystem services such as carbon sequestration, should be the subject of future investigations.

\section{Acknowledgements}

We thank H Bugmann who helped initiate this research and provided support for the LANDCLIM model, J van Leeuwen for contributions to the pollen records presented here, M Schmidt for local soil data from Lago di Origlio, WWF and S D'Angelo for access to Gorgo Basso, $\mathrm{K}$ McLauchlan for comments on an earlier version of the manuscript, and the Swiss National Science Foundation for support of project SNF PPOOP2-114886. The ENSEMBLES data used in this work were funded by the EU FP6 Integrated Project ENSEMBLES (contract number 505539).

\section{References}

Azevedo JC, Possacos A, Aguiar CF, et al. 2013. The role of holm oak edges in the control of disturbance and conservation of plant diversity in fire-prone landscapes. Forest Ecol Manag 297: $37-48$.

Calò C, Henne PD, Eugster P, et al. 2013. 1200 years of decadalscale variability of Mediterranean vegetation and climate at Pantelleria Island, Italy. Holocene 23: 1477-86.

Carrión JS, Fernández S, Jiménez-Moreno G, et al. 2010. The historical origins of aridity and vegetation degradation in southeastern Spain. J Arid Environ 74: 731-36.

Cheaib A, Badeau V, Boe J, et al. 2012. Climate change impacts on tree ranges: model intercomparison facilitates understanding and quantification of uncertainty. Ecol Lett 15: 533-44.

Colombaroli D, Marchetto A, and Tinner W. 2007. Long-term interactions between Mediterranean climate, vegetation and fire regime at Lago di Massaciuccoli (Tuscany, Italy). J Ecol 95: $755-70$.

Deil U, Culmsee H, and Berriane M. 2005. Sacred groves in Morocco: a society's conservation of nature for spiritual reasons. Silva Carelica 49: 185-201.

Di Pasquale G, Allevato E, Cocchiararo A, et al. 2014. Late Holocene persistence of Abies alba in low-mid altitude decidu- ous forests of central and southern Italy: new perspectives from charcoal data. J Veg Sci 25: 1299-310.

Garcia-Valdes R, Zavala MA, Araujo MB, and Purves DW. 2013. Chasing a moving target: projecting climate change-induced shifts in non-equilibrial tree species distributions. J Ecol 101: 441-53.

Henne PD, Elkin C, Colombaroli D, et al. 2013. Impacts of changing climate and land use on vegetation dynamics in a Mediterranean ecosystem: insights from paleoecology and dynamic modeling. Landscape Ecol 28: 819-33.

Hickler T, Vohland K, Feehan J, et al. 2012. Projecting the future distribution of European potential natural vegetation zones with a generalized, tree species-based dynamic vegetation model. Global Ecol Biogeogr 21: 50-63.

Lang G. 1994. Quartäre Vegetationsgeschichte Europas: Methoden und Ergebnisse. Jena, Germany: Gustav Fischer Verlag.

Lebreton V, Jaouadi S, Mulazzani S, et al. In press. Early oleiculture or native wild Olea in eastern Maghreb: new pollen data from the sebkha-lagoon Halk el Menjel (Hergla, Central Tunisia). Environ Archaeol; doi:10.1179/1749631414Y.0000000046.

Moriondo M, Good P, Durao R, et al. 2006. Potential impact of climate change on fire risk in the Mediterranean area. Clim Res 31: 85-95.

Peñuelas J, Ogaya R, Boada M, and Jump AS. 2007. Migration, invasion and decline: changes in recruitment and forest structure in a warming-linked shift of European beech forest in Catalonia (NE Spain). Ecography 30: 829-37.

Sadori L, Jahns S, and Peyron O. 2011. Mid-Holocene vegetation history of the central Mediterranean. Holocene 21: 117-29.

Schröter D, Cramer W, Leemans R, et al. 2005. Ecosystem service supply and vulnerability to global change in Europe. Science 310: 1333-37.

Schumacher S, Bugmann H, and Mladenoff DJ. 2004. Improving the formulation of tree growth and succession in a spatially explicit landscape model. Ecol Model 180: 175-94.

Tinner W, Colombaroli D, Heiri O, et al. 2013. The past ecology of Abies alba provides new perspectives on future responses of silver fir forests to global warming. Ecol Monogr 83: 419-39.

Tinner W, Hubschmid P, Wehrli M, et al. 1999. Long-term forest fire ecology and dynamics in southern Switzerland. J Ecol 87: 273-89.

Tinner W, van Leeuwen JFN, Colombaroli D, et al. 2009. Holocene environmental and climatic changes at Gorgo Basso, a coastal lake in southern Sicily, Italy. Quaternary Sci Rev 28: 1498-510.

Van der Linden P and Mitchell JFB. 2009. ENSEMBLES: climate change and its impacts: summary of research and results from the ENSEMBLES project. Exeter, UK: Met Office Hadley Centre. 


\section{WebPanel 1. Edaphic, topographic, and disturbance inputs to LANDCLIM}

LANDCLIM calculates monthly temperature and water availability for each model cell from soil water-holding capacity, topography, mean monthly temperature, and monthly precipitation (Schumacher et al. 2004). We estimated soil properties from local soil profiles and maps (data sources: Gorgo Basso [Crescimanno and Garofalo 2005]; Massaciuccoli [Autorità di Bacino pilota del fiume Serchio 2006]; Origlio [MWI Schmidt, unpublished soil survey]). LANDCLIM uses a cumulative beta probability density function to relate a drought index to the probability a fire will ignite and spread. The shape of this curve is defined by two parameters, $\alpha$ and $\beta$ (Henne et al. 20I3). We used two disturbance scenarios at each site - a low-disturbance, pre-human impact scenario with small, infrequent fires $(\alpha=2.5, \beta=1.5$; minimum probability $=0.1$; maximum probability $=0.8)$, and no browsing, and a moderate-disturbance scenario with small, frequent fires $(\alpha=2.0, \beta=1.5$; minimum probability $=0.17$; maximum probability $=0.8$, maximum fire size $=$ $10 \%$ of landscape), and moderate browsing (browsing intensity $=0.5$ ). These disturbance scenarios allow for the investigation of human impacts on extinct forests but may underestimate present disturbance, especially near Gorgo Basso, where fire is used to maintain open land for grazing.

\section{WebPanel 3. Ranking future climate scenarios and} comparison to pollen data

We explored the possibility of using the mean climate change projected by the nine regional climate models to drive LANDCLIM. However, when averaged, the seasonal precipitation distributions are inconsistent with every regional climate model, and simulated vegetation is distinct from the individual climate-change scenarios. We therefore considered the median impact on vegetation of the nine regional climate models to be a more useful indicator of potential vegetation outcomes. We identified the median impact scenario by calculating the squared chord distance (SCD) of each future climate scenario from the control (present climate) scenario. SCD reduces two sets of multi-dimensional species abundance data into a single measure of dissimilarity, and moderately increases the importance of rare taxa (Gavin et al. 2003). We ranked each scenario using its mean SCD from the control, and indicated the scenario with the median SCD score for each site.

We compared model output to pollen percentages of upland trees and shrubs. Because LANDCLIM does not simulate forest dynamics in wetlands, we removed all species typical of saturated soils (eg Alnus glutinosa) from the pollen sums. Upland herbaceous species were included in the pollen sum, but are not shown.

\section{WebPanel 2. Climate scenarios}

We initiated LANDCLIM from bare ground with a 2000-year model spin using present-day climatic conditions and the moderate-disturbance scenario. We generated the present climate scenarios for each site by fitting weather station data from the period 195I-2000 AD to a covariance matrix and drawing random monthly temperatures from a normal distribution, and precipitation abundances from a gamma distribution. We obtained weather station data from Mazara del Vallo, $8 \mathrm{~km}$ northwest of Gorgo Basso, and Pisa San Giusto Airport, 15 km south of Lago di Massaciuccoli. Because complex topography surrounds Lago di Origlio, we used weather station data that were interpolated to a I-ha grid by the DAYMET model (Thornton et al. 1997; Swiss Federal Institute for Forest, Snow, and Landscape Research,WSL). Observed temperature and precipitation data from 195I-2010 AD were used for the final 60 years of the initiation period. Vegetation simulated at $2010 \mathrm{AD}$ was then used as a starting point for all future simulations.

We developed future climate scenarios for each site from the output of nine regional climate models. These models projected climate change in Europe for the period 195I-2100 AD under the IPCC AIB emissions scenario for the ENSEMBLES project (Van der Linden and Mitchell 2009). We compiled monthly climate data from each model for 195 I-2 I00AD from the $625-\mathrm{km}^{2}$ grid cell that contains each study site. We used I95I-2000 AD as a reference period for the mean and variability in monthly temperatures and precipitation. Deviations from the reference period were calculated for 30-year intervals centered on 2025 , 2055, and 2085 AD. We generated climate scenarios by adding the deviations to monthly temperatures and precipitation abundances drawn from weather station data as described above for the present climate scenarios. For 20II-2I00 AD, we used linear interpolation between the 30 -year intervals to estimate the deviations, and maintained the 2085 deviations for 210I-3000 AD.

\section{WebReferences}

Autorità di Bacino pilota del fiume Serchio. 2006. Carta della permeabilità, dei tipi di suolo e della infiltrazione potenziale. www.autorita.bacinoserchio.it/cartografie/massaciuccoli. Viewed 23 Jun 2015.

Crescimanno G and Garofalo P. 2005. Application and evaluation of the SWAP model for simulating water and solute transport in a cracking clay soil. Soil Sci Soc Am J 69: 1943-54.

Gavin DG, Oswald WW, Wahl ER, and Williams JW. 2003. A statistical approach to evaluating distance metrics and ana$\log$ assignments for pollen records. Quaternary Res 60: 356-67.

Henne PD, Elkin C, Colombaroli D, et al. 2013. Impacts of changing climate and land use on vegetation dynamics in a Mediterranean ecosystem: insights from paleoecology and dynamic modeling. Landscape Ecol 28: 819-33.

Schumacher S, Bugmann H, and Mladenoff DJ. 2004. Improving the formulation of tree growth and succession in a spatially explicit landscape model. Ecol Model 180: 175-94.

Thornton PE, Running SW, and White MA. 1997. Generating surfaces of daily meteorological variables over large regions of complex terrain. J Hydrol 190: 214-51.

Van der Linden P and Mitchell JFB. 2009. ENSEMBLES: climate change and its impacts: summary of research and results from the ENSEMBLES project. Exeter, UK: Met Office Hadley Centre. 